Juridical Analysis of Diffabel Wives in Article 57 Letter (b) Compilation of Islamic Law

\title{
JURIDICAL ANALYSIS OF DIFFABEL WIVES IN ARTICLE 57 LETTER (b) COMPILATION OF ISLAMIC LAW
}

\author{
Amir Fiqih Alqadafi \\ Mahasiwa Program Doktor IHPSI (Ilmu Hukum dan Pranata Sosial Islam \\ UIN Sunan Kalijaga Yogyakarta \\ email : fiqih_qadafi@yahoo.com
}

\begin{abstract}
One of the strongest reasons for proposing polygamy as contained in article $\mathbf{5 7}$ letter $b$ is that teh wife have a body defect (imperfect body) so that the husban can file a divorce and disability claim which is called diffable. There are regulations that regulate the similarity of rights before the law such as human rights, law number 4 of 1997 concerning persons with disabilities, the constitution of the Republik of Indonesia years 1945, law number 19 years 2011 concerning the ratification of disability conventions and law number 18 years 2016 concerning disability. Formulation of the problem is 1 ) what is the jurdical analysis of legal protection for women with disabilities in article 57 letter b KHI. 2) what is the solution or form of legal protection for women with disabilities in article 57 letter b KHI. Methodes is qualitative descreibed by the statute approach and conceptual aprroach. Type of library research and data collection in documentation and data analysis using content analiysis. Validity of data in credibility and data triangulation. Conclusion, the provisions of article 57 letter b conflict with human rights and disability law there are law number 4 years 1997 concerning persons with disabilities, the Republik Of Indonesia years 1945 artcle 27, law number 19 years 2011 concerning convention on the right of persons with disabilities and law number 8 years 2016 concerning disability and the jugde must tigthen not to grant the husban who wants to be polygamy for the reason of the disability.
\end{abstract}

Keyword : Wives, Diffable, Compilation Of Islamic Law

\section{PENDAHULUAN}

Salah satu bentuk isu-isu minoritas yang perlu mendapat perhatian khusus dalam Kompilasi Hukum Islam (KHI) ialah su yang berkenaan tentang difabel. ${ }^{1}$ Adanya isu mengenai difabel yang sangat krusial dan berkaitan erat dengan Hak

${ }^{1}$ Istilah difabel diambil dari ringkasan kalimat different ability people (seseorang dengan kemampuan berbeda) atau people with different ability yang dibedakan dengan disabel atau people with disability (orang dan pencapaian yang berbeda. Lihat Mochamad Sodik, Pembacaan Progresf Terhadap Fikih Keluarga (Kritik Terhadap KHI dan RUU HTPA) vol 4 No. 1 Januari 2012, 121.

Falasifa, Vol. 9 Nomor 2 September 2018 | 111 
Asasi Manusia $(\mathrm{HAM})^{2}$ perlu mendapat perhatian lebih agar tidak meruntuhkan elegansi fikih dalam menyikapi permasalahan-permasalahan yang membutuhkan solusi atau pemecahannya sehingga fikih menjadi humanis atau tidak rigid (kaku) menghadapi permasalahan yang baru dalam mereformulasi hukum Islam yang kemudian diejawantahkan dalam Kompilasi Hukum Islam. ${ }^{3}$

Pasal KHI yang menyinggung persoalan difabel yang berkenaan dengan gender, disabilitas dan isu-isu minoritas ${ }^{4}$ ialah pasal 57 huruf (b) yang menyatakan bahwa: istri mendapat cacat badan atau penyakit yang tidak dapat disembubkan sehingga dengan pernyataan pasal tersebut dapat menjadi celah bagi suami dapat menjatuhkan talak atau mengajukan gugatan perceraian dan menjadi alasan yang kuat untuk mengajukan poligami di Pengadilan Agama. ${ }^{5}$

Difabel yang kemudian disebut dengan istilah disabilitas ini merupakan orang yang memiliki perbedaan fisik maupun mental dengan orang yang normal yang memerlukan perhatan khusus yang pada dasarnya keterbatasan tersebut tidak berhubungan dengan ketidakmampuan untuk melakukan aktifitas sebagaimana layaknya manusia normal. ${ }^{6}$ Seseorang yang mengalami kehilangan fungsi (fisik dan mental) baik sebagian maupun keseluruhan bisa digantikan menggunakan disabilitas. Disabilitas merupakan sebuah hasil dari interaksi antara keterbatasan fungsi fisik atau mental, faktor personal di luar keterbatasan fungsi, dan respon sosial. Faktor yang disebutkan terakhir tadi melahirkan respon sosial yang lebih luas, yang mendukung hambatan atas ketidakmampuan tersebut. ${ }^{7}$

Penyadang Disabilitas termasuk mereka yang memiliki ketrebatasan fisik mental

\footnotetext{
${ }^{2}$ Undang-Undang Nomor 39 tahun 1999 tentang HAM

${ }^{3}$ Kompilasi Hukum Islam merupakan pedoman bagi hakim Pengadilan Agama dalam memutuskan perkara

${ }^{4}$ Perempuan dalam ketentuan pasal tersebut merupakan kelompok rentan difabel sehingga perlindungan hukum terhadap perempuan difabel perlu untuk mendapat perhatian khusus sebab perempuan yang difabel bukanlah keinginannya lahr dalam keadaan seperti itu. Inilah yang kemudian mendorong peraturan yanng berkenaan dengan difabel untuk mengakomodir isu-isu yang masih belum dianggap krusial.

${ }^{5}$ Pengadilan Agama merupakan Pengadilan bagi orang-orang Islam dimana ketika seseorang mengajukan permohonan perkara maka hakim tidak boleh menolak perkara yang datang kepadanya karena dalam peraturan telah ditetapkan bahwa tugas hakim menerima, memeriksa dan memutuskan perkara yang kemudian dengan adanya perturan yang semacam ini jika dikaitkan dengan pasal 57 huruf b menjadi menjadi alasan kuat untuk suami mengajukan poligami.

${ }^{6}$ Hari Kurniawan, Aksesibilitas Peradilan Bagi Penyandang Disabiltas (Yogyakarta: PUSHAM UII, 2015), 54.

${ }^{7}$ Hari Kurniawan mengutip dari WHO, International Clarification Of Functioning, Disability and Health (Worid Health Organization: 2001).
}

112 | FaLASIFA, Vol. 9 Nomor 2 September 2018 
Juridical Analysis of Diffabel Wives in Article 57 Letter (b) Compilation of Islamic Law

intelektual, atau sensorik dalam jangka waktu lama dimana ketika berbadapan dengan berbagai hambatan, hal ini dapat menghalangi partisipasi penuh dan efektif mereka dalam masyarakat bersadarkan kesetaraan dengan yang lainnya. (Pasal 1 Konvensi Mengenai Hak-Hak Penyandang Disabilitas) $^{8}$

Undang-Undang Nomor 4 Tahun 1997 Tentang Penyandang Cacat pasal 1 ayat 1 yang menyatakan:

"Penyandang Cacat adalah setiap setiap orang yang mempunyai kelainan fisik dan/atau mental, yang dapat menganggu atau merupakan rintangan dan bambatan baginya untuk melakukan kegiatan secara selayaknya, yang terdiri dari a). penyandang cacat fisik, b). penyandang cacat mental, c). penyandang cacat fisik dan mental ${ }^{9 ”}$

Definisi disabilitas yang ada dalam konvensi mengakar dari sumber pendekatan sosial dimana pada tatarannya tidak melihat pada sisi permasalahan disabilitas sebagai masalah individu. Bahkan saat ini, model sosial yang diterapkan sangat erat hubungannya dengan kerangka hak asasi manusia. Gabungan pendekatan sosial dan hak asasi manusia menerapkan sebuah pandangan baru. Kecacatan (impairment) maupun ketrbatasan fungsional, sesungguhnya tidak berhubungan dengan ketidakmampuan dalam melakukan aktifitas maupun partisipasi sosial. Masyarakat, lingkungan bahkan Negara dianggap gagal memenuhi kebutuhan penyandang disabilitas. ${ }^{10}$

Isu disabilitas merupakan bagian yang tidak terpisahkan dari isu hak asasi manusia. Berangkat dari kenyataan bahwa hak asasi manusia adalah hak yang melekat pada setiap manusia. Maka, pengecualian atau pengucilan sosial yang dialami oleh penyandang disabilitas adalah pelanggaran hak. Jaminan atas kesetaraan, kesamaan hak dan partisipasi penuh juga seharusnya melekat pada

\footnotetext{
${ }^{8}$ Undang-Undang Nomor 19 Tahun 2011 Tentang pengesahan konvensi mengenai Hak-Hak Penyandang Disabilitas.

${ }^{9}$ Undang-Undang Nomor 4 Tahun 1997. Sebagai warga negara Indonesia, kedudukan, hak, kewajiban, dan peran penyandang cacat adalah sama dengan warga negara lainnya. Hal ini sesuai dengan UUD1945, dalam Pasal 27 : Setiap warga negara berhak memperoleh pekerjaan dan penghidupan yang layak bagi kemanusiaan. Kemudian ada penegasan lagi pada amandemen UUD 1945 yang mengatur tentang Hak Azasi Manusia, yang menandakan bahwa negara telah memberikan perhatian yang sungguh-sungguh kepada harkat dan martabat manusia dalam kehidupan berbangsa dan bernegara.

${ }^{10}$ Hari Kurniawan dalam bukunya menyatakan bahwa impairment diartikan sebagai gangguan atau kerusakan fungsi fisik, mental, kejiwaan maupun anatomi tubuh baik sebagian maupun keseluruhan. Impairment berkontribusi pada terjadinya disabilitas.
}

Falasifa, Vol. 9 Nomor 2 September $2018 \mid 113$ 
penyandang disabilitas. ${ }^{11}$ Persamaan hak harus dapat dirasakan oleh semua lapisan masyarakat tanpa terkecuali sehingga rasa keadilan pun merata termasuk mengenai difabel ini. Pengkategorian difabel perlu diperjelas sehingga tidak menimbulkan multitafsir. Cara sederhana dalam memahami disabilitas adalah dengan mengenalinya dalam 3 (tiga) faktor. Masing-masing adalah faktor kerusakan fungsi; baik fisik maupun mental. Kemudian faktor kondisi personal serta faktor lingkungan dan masyarakat. Kerusakan fungsi baik fisik atau mental merupakan sesuatu yang paling mudah kita kenal. Contohnya buta, tuli, amputasi tangan atau kaki, baik sebagian maupun keseluruhan. ${ }^{12}$ Dengan melihat penjelasan tentang difabel di atas maka jelaslah bahwa keberadaan kaum difabel adalah penanganan yang serius dan harus segera dilakukan sehingga dalam upaya membangun fikih pemberdayaan, perlu adanya suatu penegasan sikap dengan cara memihak kelompok rentan yang sering kali terpinggirkan dan dirugikan dan diabaikan agar pasal-pasal yang problematis yang berkeadilan gender mendapat porsi perhatian yang sejajar yaitu persaam hak di depan hukum.

Berangkat dari latar belakang diatas, maka Peneliti tertarik untuk mengkaji isu-isu yang belum dianggap krusial dalam KHI yaitu tentang perempuan yang difabel. Perempuan yang difabel dalam hal ini adalah perempuan yang cacat karena lahir dan karena bawaan bisa karena ketika menikah kemudian mengalami kecelakaan atau karena faktor lain sehingga menngalami cacat badan dengan judul: Analisis Yuridis Terhadap Perempuan Difabel Dalam Ketentuan Pasal 57 Huruf (b) Kompilasi Hukum Islam. Hal ini menarik untuk dikaji mengingat pasal tersebut kurang ramah terhadap difabel.

\section{RUMUSAN MASALAH}

Masalah dalam hal ini adalah suatu keadaan yang bersumber dari hubungan antara dua faktor atau lebih yang menghasilkan situasi yang menimbulkan tandatanda yang memerlukan upaya untuk mencari suatu jawaban. Faktor tersebut berupa konsep, data empiris, pengalaman, atau unsur lainnya yang jika ditempatkan secara berpasangan akan menghasilkan kesukaran dan tanda tanya. ${ }^{13}$ Fokus kajian ialah sebagai berikut :

1) Bagaimana analisis yuridis perlindungan hukum terhadap perempuan difabel dalam pasal 57 huruf $\mathrm{b}$ KHI?

2) Bagaimana solusi atau bentuk perlindungan hukum terhadap perempuan

\footnotetext{
${ }^{11}$ Kurniawan, Aksesibiltas,...., 54.

${ }^{12}$ Kurniawan, Aksesibiltas,...., 55.

${ }^{13}$ Lexy, metodologi penelitian kualitatif (Bandung: Remaja Rosdakarya, 2010), 93.
}

114 | FaLASIFA, Vol. 9 Nomor 2 September 2018 
difabel dalam pasal 57 huruf b KHI?

\section{TUJUAN PENELITIAN}

Tujuan dari penelitian ini sebagaimana dari rumusan masalah untuk mendekripsikan analisis yuridis perlindungan hukum terhadap perempuan difabel dalam pasal 57 huruf b KHI dan menemukan kedudukan istri yang cacat badan dalam KHI Pasal 57 huruf (b)

\section{LANDASAN TEORI}

Kondisi difabel yang kurang mendapatkan perhatian khusus akan mengalami suatu hambatan psikologis terhadap dirinya dan merasa asing serta menarik diri dari pergaulan dan merasakan serba kekurangan yang pada dasarnya akan kehilangan kepercayaan diri.

Lahirnya penemuan baru akibat kemajuan ilmu dan teknologi (iptek), berimplementasi pula terhadap paradigma dalam membentuk pola pikir yang membawa konsekuensi yang sesuai dan tepat (logis) sehingga melahirkan peraturan baru di dalam tatanan masyarakat. Teknologi dianggap sebagai bagian dari tubuh manusia dalam mengarahkan intensionalitas manusia kepada dunia kehidupan di sekitarnya ${ }^{14}$ Dalam kehidupan manusia di era global ini akan selalu berhubungan dengan teknologi. Teknologi pada hakikatnya adalah alat untuk mendapatkan nilai tambah menghasilkan produk yang bermanfaat. Teknologi sekarang ini berkembang pesat. Teknologi telah memperngaruhi manusia akan kehidupannya sehari-hari, sehingga jika gagap teknologi akan terlambat menguasai teknologi, dan akan tinggal pula untuk memperoleh kesempatan untuk maju ${ }^{15}$ di zaman cyber dan teknologi yang serba modern ini berbagai solusi kehidupan berhasil diatasi ${ }^{16}$ sehingga dengan adanya kemajuan iptek dan peradaban maka akan sangat membantu untuk menyelesaikan permasalahan yang mungkin tidak ada (penjelasan) daripada nash baik di dalam al-Qur'an maupun alhadits dan kaum difabel bisa menggunakan dan memanfaatkan alat-alat tekhnologi yang telah ada.

Peraturan perundang-undangan yang bersifat mengikat harus ditaati oleh semua lapisan masyarakat baik yang pusat maupun ditingkat daerah yang

\footnotetext{
${ }^{14}$ Francis Lim, " Filsafat Teknologi: Don Ihde Tentang Manusia dan Alat (Yogyakarta: KANISIUS, 2008), 107.

${ }^{15}$ Munir,'Pembelajaran Jarak Jauh : Berbasis Teknologi Informasi dan Kommnikasi (Bandung: ALFABETA, 2009), 29.

${ }^{16}$ Erbe Sentanu, Quatum Ikhlas :Teknologi Aktivasi Kekuatan Hati The Power Of Positive Feeling (Jakarta: PT. Elex Media Komputindo, 2011), 58.
}

FaLASIFA, Vol. 9 Nomor 2 September 2018 | 115 
esensinya ialah berbentuk keputusan tertulis sehingga menjadi kaidah hukum tertulis (geschrevenrecht writen law). Peraturan perundang-Undnagan yang dimaksud dalam hal ini ialah seperti HAM, Undang-Undang Nomor 4 Tahun 1997 Tentang Penyandang Cacat, Undang-UndangDasarRepublik Indonesia Tahun 1945 Pasal 27, Undang-Undang Nomor 19 Tahun 2011 Tentang pengesahan konvensi Disabilitas dan Undang-Undang Nomor 8 Tahun 2016 Tentang Disabilitas

Berdasarkan rumusan masalah tujuan yang hendak dicapai adalah bahwa hipotesis peneliti ialah apabila Pasal 57 huruf (b) dalam KHI ditinjau kembali oleh Pemerintah maka KHI akan bersifat humanistis sehingga para istri yang mengalami cacat badan akan mendapatkan perlindungan hukum.

\section{METODE PENELITIAN}

Penelitian ini menggunakan pendekatan kualitatif ${ }^{17}$ deskriptif karena mendeskripsikan data dari teori yang didapat dan menggunakan pendekatan perundang-undangan (Statute Approach), ${ }^{18}$ dan pendekatan konseptual (Conseptual Approach). Hal ini dilakukan karena Penelitian tidak beranjak dari aturan hukum yang sudah ada, serta hal itu dilakukan karena memang belum ada atau tidak ada aturan hukum yang kuat atas masalah yang dihadapi. ${ }^{19}$ Sehingga penelitian ini secara garis besar menggunakan pendekatan kualitatif dengan spesifik pada peraturan perundang-undangan yang berlaku dan jenis penelitian ini adalah Library Research (kajian pustaka) dan agar lebih relevan dalam memaksimalkan penelitian ini, karena memusatkan pada koreksi secara mendalam tentang kesamaan hak yang terdapat dalam Undang-Undang dan Kompilasi Hukum Islam Indonesia kaitannya dengan perempuan yang difabel dalam ketentuan pasal 57 huruf (b) dengan mengambil sumber penelitian melalui Kompilasi Hukum Islam, Undang-Undang tentang disabilitas. Bahan hukum yang digunakan adalah

${ }^{17}$ Lexy J Moleong, Metodologi Penelitian Kualitatif (Bandung: Remaja Rosdakarya, 2014), 11. Menurut lexi, kualitatif yang dimaksud berupa kata-kata, gambar, dan bukan berupa angka-angka dan segala data yang dikumpulkan dapat dijadikan kunci terhadap apa yang sudah diteliti

${ }^{18}$ Pendekatan perundang-undangan adalah menelaah secara mendalam tentang keberadaan sebuah peraturan, menelaah muatannya dari kaca mata Metodologi, sehingga perlu kiranya menelaah juga dasar ontologisnya. Lihat Peter Mahmud Marzuki, Penelitian Hukum Edisi Revisi (Jakarta: Pranada Media Group, 2015), 142. Bandingkan dengan Jhonny Ibrahim, Teori \& Metodologi Penelitian Hukum Normatif (Malang: Banyumedia, 2010), 302.

${ }^{19}$ Peter Mahmud Marzuki, Penelitian Hukum Edisi Revisi (Jakarta: Pranada Media Group, 2015), 177.

116 | FaLASIFA, Vol. 9 Nomor 2 September 2018 
Kompilasi Hukum Islam, Undang-Undang tentang Difabel dan HAM. Sedangkan metode pengumpulan data ${ }^{20}$ yang digunakan dalam penelitian ini menggunakan metode dokumentasi, dokumentasi merupakan catatan peristiwa yang sudah berlalu, dokumentasi bisa berbentuk tulisan, gambar, atau karya-karya monumental dari seseorang. ${ }^{21}$ Tekhnik pengumpulan data merupakan langkah paling strategi dalam penelitian. ${ }^{22}$ Sehingga sangat penting diterapkan dalam penelitian. Adapun tekhnik pengumpulan data dalam penelitian ini adalah dokumentasi dan langkah-langkah pengumpulannya ialah sebagai berikut: Tahap pertama, Melakukan pengumpulan data ${ }^{23}$ tentang formulasi perempuan difabel dalam KHI, serta mengumpulkan konsep-konsep dan legalitas sebuah UndangUndang Hukum. Tahap kedua Menelaah secara mendalam dokumen-dokumen yang telah dikumpulkan Tahap ketiga Mencari data-data yang terkait dengan perempuan cacat badan atau difabel dalam buku I tentang Perkawinan.

\section{HASIL DAN PEMBAHASAN}

\section{Analisis Yuridis Perlindungan Hukum Terhadap Perempuan Difabel Dalam}

\section{Pasal 57 Huruf (b) KHI}

Wacana yang ditawarkan dalam pengistilahan difabel ini mengandung makna yang lebih bijak, sebab memposisikan individu yang memiliki hambatan sementara maupun permanen dalam menjalankan aktifitas mereka dalam kehidupan sehari-hari dengan tidak mersaterpinggirkan atau pun merasa mengalami perbedaan hak. Peristilahan ini berpengaruh secara langsung terhadap perlakuan masyarakat maupun pemerintah terhadap keberadaan "difable" secara menyeluruh. Namun demikian, konsepsi tersebut bisa pula berbeda dan berubah secara historis sesuai perkembangan yang terjadi dalam masyarakat maupun Negara. ${ }^{24}$ Difabel merupakan istilah yang diindonesiakan dari diffable (people with

${ }^{20}$ Data yang dimaksud dalam penelitian ini adalah bahan hukum yang terkiat dengan penelitian.

${ }^{21}$ Sugiyono, Penelitian...., 240.

${ }^{22}$ Sugiyono, Metode Penelitian Kuantitatif dan Kualitatif dan R\&D (Bandung: Alfabeta, 2010), 224.

${ }^{23}$ Data yang dimaksud dalam penelitian ini adalah bahan hukum yang terkiat dengan penelitian.

${ }^{24}$ RisnawatiUtami, 2012, MakalahUntuk Intermediate Human Rights Training BagiDosenHukum Dan HAM di Balikpapan, KonvensiTentangHakHakPenyandangDisabilitas: DalamPerspektifKebijakanPublik Di Indonesia, Kerjasama PUSHAM UII dengan Norwegian Centere for Human Rights. DalamJurnalInovatif: Rahayurepindowatyharahap, perlindunganhukumterhadappenyandangdisabilitasmenurut convention on the rights of persons with disabilities (crpd) vol VIII nomor 1, 2015.Lihat 
different abilities). Istilah difabel memberi peluang untuk memperhatikan masyarakat dengan kondisi berbeda sehingga istilah difabel juga mencakup orang tua lanjut usia (lansia), wanita hamil, dan kelompok lainnya yang memiliki kemampuan berbeda dengan kelompok masyarakat umumnya. ${ }^{25}$ Penggunaan istilah difabel juga mengajak kita memahami adanya keberagaman dan menghargai tingkat kemampuan antara satu orang dan lainnya. Stevie Wonder, Penyanyi terkenal tunanetra menjadi salah satu bukti tingkat kemampuan berbeda kaum"difabel"dalam konotasi positif. ${ }^{26}$ Bahkan, masih banyak peraturan yang menyebutkan syarat tidak cacat jasmani untuk jenis pekerjaan yang tidak ada kaitannya dengan kecacatan jasmani. Sekalipun secara internasional dan nasional gerakan hak asasi manusia dan pembangunan ekonomi mengalami perbaikan, secara umum kelompok ini masih berada di garis terakhir untuk dapat menikmatinya. ${ }^{27}$ Maka di sini perlu untuk memberikan pemahaman terhadap kaum difabel dimana persoalan yang menjadi hambatan ialah persoalan kesamaan hak agar tidak terjadi ketimpangan sosial. Analisis terhadap kaum difabel membantu memahami bahwa pokok persoalannya yakni sistem dan struktur yang tidak adil dari ideologi 'normalisme' bekerja dan membawa korban. Ideologi ini

artikel oleh Arif Maftuhin, Difabel dan Penyandang Disabilitas. PLD UIN Sunan Kalijaga, September 2014. Dalam artikel ini membedakan kata difabel dan kata disabilitas. Kata difabel adalah kata benda (noun) mengacu kepada "manusianya", yaitu orang-orang yang menyandang perbedaan level fungsi jasmani dan rohani. Sedangkan disabilitas adalah kata benda yang digunakan untuk jenis kecacatan yang disandangnya misalnya ketulian dan kebisuan.

${ }^{25}$ Mujimin, W. M., Dinamika Pendidikan (Penyediaan Fasilitas Publik yang Manusiawi Bagi Aksesibilitas Difabel), No.1/Th.XIV/Mei 2007. Yogyakarta.: Universitas Negeri. Dalam M. Isya dkk., aksesibilitas jembatan penyeberangan orang (jpo) bagi penyandang difabel di kota banda Aceh menurut persepsi masyarakat. Teras Jurnal, Vol.5, No.1, Maret 2015.

${ }^{26}$ Mujimin, W. M., "Dinamika Pendidikan (Penyediaan Fasilitas Publik yang Manusiawi Bagi Aksesibilitas Difabel), No.1/Th.XIV/Mei 2007. Yogyakarta.: Universitas Negeri), 62 .

${ }^{27}$ Diperkirakan ada 650 juta penyandang disabilitas di dunia. $20 \%$ dari penduduk dunia yang termiskin adalah penyandang disabilitas; $98 \%$ dari anak-anak yang menyandang disabilitas di negara berkembang tidak mengenyam pendidikan; $30 \%$ anakanak jalanan di dunia adalah penyandang disabilitas; dan $3 \%$ penyandang disabilitas yang dewasa adalah buta huruf dan dibanyak negara hampir $1 \%$ penyandang disabiliats yang buta huruf adalah wanita. Lihat, Andrew Byrnes, Cs, 2007, "Disabilities, From Exclusion to Equality: Realizing the Rights of Persons With Disabilities", United Nations, Geneve, 1. Dalam Jurnal Inovatif: Rahayu repindowaty harahap, perlindungan hukum terhadap penyandang disabilitas menurut convention on the rights of persons with disabilities (crpd) vol VIII nomor 1, 2015.

118 | FaLASIFA, Vol. 9 Nomor 2 September 2018 
telah mengorbankan jutaan orang, baik yang dicacatkan maupun yang merasa normal termasuk didalamnya hambatan dalam berinteraksi sosial (hambatan sikap/attitudinal barrier) maupun hambatan arsitektural (hambatan secara fisik) adalah bagian dari salah satu bentukan budaya atau "image" masyarakat Indonesia dalam memahami persoalan difable. ${ }^{28}$ hambatan-hambatan fisik yang dialami oleh kaum difabel perlu adanya suatu solusi untuk mengatasi hambatan-hambtan tersebut. Hambatan fisik bukanlah suatu alasan yang tepat untuk tidak memperoleh penghidupan dan jaminan yang layak.

Pasal 57 huruf (b) tidak sejalan dengan Peraturan perundang-undangan antara lain : Pasal 5 Undang-Undang nomor 4 Tahun 1997 tentang Penyandang Cacat yang menyatakan:

"Setiap penyandang cacat mempunyai hak dan kesempatan yang sama dalam segala aspek kehidupan dan penghidupan" 29

Konstitusimenyatakanbahwa Indonesia adalah Negara yang berkesetaraan. Pasal 27 Undang-UndangDasarRepublik Indonesia Tahun 1945 menyatakan:

"Segala warga negara bersamaan kedudukannya di dalam hukum dan pemerintah dan wajb menjunjung hukum dan pemerintahan itu dengan tidak ada kecualinya." ${ }^{30}$

Pasal ini merupakan rujukan yang harus benar-benar melandasi seluruh produk dan ketentuan moral danhukum yang mengikat ${ }^{31}$ Persamaan ini termasuk bagi penyandang disabilitas yang memiliki hak dan kesempatan yang sama dengan manusia normal dalam segala aspek kehidupan dan penghidupan termasuk juga setara di hadapan hukum, tanpa diskriminasi, serta mendapatkan perlindungan dan manfaat hukum yang setara yang mana tertuang di dalam Undang-Undang sebagai berikut :

Undang-Undang nomor 8 tahun 2016 tentang Disabilitas pasal 1 menyatakan : ${ }^{32}$ Penyandang disabilitas adalah setiap orang yang mengalami keterbatasan fisik, intelektual, mental dan/atau sensorik dalam jangka waktu

\footnotetext{
${ }^{28}$ James I. Charlton, 1998, Nothing About Us Without Us, Disability Oppression and Empowerment, University of California Press Barkeley and Los Angeles, California. Dalam Jurnal Inovatif: Rahayu repindowaty harahap, perlindungan hukum terhadap penyandang disabilitas menurut convention on the rights of persons with disabilities (crpd) vol VIII nomor 1, 2015.

${ }^{29}$ Undang-Undang nomor 4 Tahun 1997 tentang Penyandang Cacat.

${ }^{30}$ Undang-Undang Dasar Negara Republik Indonesia Tahun 1945.

${ }^{31}$ Siswono Yudo Husodo," Menuju Welfare State, Kumpulan Tulisan tentang Kebangsaan, Ekonomi, dan Politik (Jakarta: Baris Baru, 2009), 5.

${ }^{32}$ Undang-Undang Nomor 8 Tahun 2016 Tentang Disabilitas
}

FALASIFA, Vol. 9 Nomor 2 September $2018 \mid 119$ 
Amir Fiqih Alqadafi

lama yang dalam berinteraksi dengan lngkungan dapat mengalami hambatan dan kesulitan untuk berpartisipasi secara penuh dan efektif dengan warga negara lainnya berdasarkan kesamaan hak.

Pasal 5 ayat 1 huruf a s/d huruf v menyatakan : "penyandang disabilitas memiliki hak :a) hidup, b) bebas dari stigma, c) privasi, d) keadilan dan perlindungan bukum, e) pendidikan, f) pekerjaan, kewrausabaan, dan koperasi, g) kesehatan, b) politik, i) keagamaan j) keolahragaan k) kebudayaan dan pariwisata, l) kesejahteraan sosial, m) aksesibilitas, n) pelayanan publik, o) perlindungan dari bencana, p) babilitasi dan rebabilitasi, q) konsesi, r) pendataan, s) bidup secara mandiri dan dilibatkan dalam masyarakat, t) berekspresi, berkomunikasi dan memperoleh nformasi, u) berpindah tempat dan kewarganegaraan, v) bebas dari tindakan deskriminasi, penelantaran, penyiksaan dan eksploitasi.

Sehingga dengan demikian kaum disabilitas terjamin kehidupannya dan endapatkan kesaamaan hak di depan hukum sehingga peraturan perundangundangan ini dapat mengakomodasi setiap warga Indonesia tanpa terkecuali termasuk dalam hal ini adalah perlindungan terhadap perempuan untuk mendapatkan keadilan sebagaimana Undang-Undang Nomor 19 Tahun 2011 tentang pengesahan konvensi mengenai Hak-Hak Penyandang Disabilitas pasal 6 (Penyadang Disabilitas Perempuan) angka 1 dan 2 sebagai berikut : ${ }^{33}$

Angka 1 menyatakan : Negara-negara pihak mengakui bahwa penyandang disabilitas perempuan dan anak perempuan adalah rentan terbadap deskriminasi ganda, dan dalam kaitan ini harus mengambil tindakan kebijakan-kebijakan untuk menjamin penikmatan penuh dan setara bagi mereka atas semua bak asasi manusia dan kebebasan fundamental

Angka 2 menyatakan : Negara-negara pibak barus mengambil semua kebijakan yang sesuai untuk menjamin pengembangan, pemajuan, dan pemberdayaan perempuan secara penuh, dengan bertujuan untuk memberikan jaminan kepada mereka atas pelaksanaan dan penikmatan bak asasi manusia dan kebebasan fundamental sebagaimana ditetapkan dalam Konvensi ini.

Dengan demikian bahwa ada kesamaan hak bag perempuan dan adanya jaminan perlindungan hukum yang melahirkan keadilan yang sama dan pada dasarnya Islam justru mengakomodasi kesetaraan dan keadilan di antara laki-laki

${ }^{33}$ Nomor 19 Tahun 2011 yang berkaiatn dengan Disabilitas. Pengesahanpengesahan Konvensi Mengenai Hak-hak Penyandang Disabilitas tersebut sungguh memiliki nilai strategis dan sejarah baru dalam pembaharuan sistem hukum nasional khususnya dalam hal pemenuhan hak-hak bagi penyandang disabilitas.

120 | FaLASIFA, Vol. 9 Nomor 2 September 2018 
dan perempuan meski yang membedakan hanya kodrat masing-masing. ${ }^{34}$ Namun dalam kenyataannya, perempuan lebih dituntut untuk berperilaku nrimo (menerima) tentang apa yang ditentukan baginya. Sementara lakilaki lebih terbiasa dan terlatih untuk melakukan hegemoni dan mengambil keputusan untuk kaum perempuan dengan maskulinisasi epistemologis. ${ }^{35}$ Kuatnya bangunan ketidakadilan gender dan seksualitas semacam itu tidak dapat lagi untuk dibiarkan. Diperlukan keberanian melakukan evaluasi terhadap persoalan tersebut. ${ }^{36}$ Salah satu cara penyelesaian kultural yang dapat ditempuh adalah dengan melakukan kajian dengan perspektif kesetaraan dan keadilan gender dalam wacana fikih. Berkenaan dengan kesetaraan dan keadilan gender mengacu pada empat indikator yaitu suami istri sama-sama memiliki akses dalam kehidupan rumah tangga, memperoleh peran-peran seimbang dalam rumah tangga menerima wewenang dan tanggungjawab khususnya dalam pengambilan keputusan serta sama-sama mendapatkan manfaat dalam kehidupan rumah tangga. Dalam konteks atau tataran ranah hukum keluarga, bahwa tujuan perkawinan adalah untuk membentuk keluarga yang sakinah dan kekal dapat mengandung maksud bahwa asas perkawinan dalam Islam adalah monogami (satu suami dengan satu istri). Kalaupun poligami harus ditempuh, maka hal itu merupakan pintu darurat dengan persyaratan yang sangat ketat. Hal ini beda konteksnya jika pada saat menikah si istri tidak mengalami atau tidak ditemukan cacat badan namun pasca pernikahan si istri mengalami cacat badan yang diakibatkan oleh kecelakaan ataupun oleh faktor-faktor yang lain kemudian suami bermaksud poligami karena ada peraturan yang mengatur tentang dibolehkannya menikah lagi atau cacat badan permanen seperti tidak dapat melahirkan namun jika masih bisa disembuhkan dengan alat tekhnologi maka alasan berpoligami ialah kurang tepat. Maka, untuk mewujudkan keluarga sakinah perlu untuk menjunjung tinggi nilainilai kesetaraan dan keadilan di dalam keluarga misalnnya menjaga kejujuran, saling percaya dan mengayomi, ketersediaan sandang, pangan, papan, pendidikan, dan kesehatan, serta terjaminnya hak-hak reproduksi, pengayoman yang cukup dalam hal pendidikan, keagamaan dan tidak melakukan kekerasan dalam rumah tangga disampinng itu perlu memperhatikan dan memahami perauran-peraturan

${ }^{34}$ Perempuan dan laki-laki dapat diketahui dengan melihat pada ciri-ciri yang menonjol seperti bentuk badan dan yang paling bisa di bedakan adalah bahwa perempuan itu melahirkan.

${ }^{35}$ Mufidah Ch, "Psikologi Keluarga Islam: Berwawasan Gender (Malang: UIN Maliki Press, 2013), 215.

${ }^{36}$ Saparinah Sadli, Sekapur Sirih, dalam Masdar F. Mas'udi, Islam dan Hak-hak Reproduksi Perempuan (Bandung: Mizan, 2000), 14-19.

FALASIFA, Vol. 9 Nomor 2 September 2018 | 121 
yang berkenan dengan keluarga yang telah ditaur dalam Undang-Undang.

Sejak disahkannya Undang-Undang Perkawinan, telah berlangsung perkembangan masyarakat yang sangat cepat. Pada saat yang sama, kesadaran terhadap pemenuhan hak-hak perempuan dan anak serta tuntutan penegakan prinsip keadilan gender menyebar semakin luas. Tidak bisa diingkari, keadilan gender telah menjadi keharusan zaman. ${ }^{37}$ Substansi dari ayat tentang poligami pada dasarnya adalah pelarangan poligami secara bertahap, sebagaimana substansi dari ayat tentang perbudakan yang bertujuan untuk penghapusan perbudakan sehingga harus dipahami maksud dari yang tersirat dan yang tersurat. Keadaanyang seperti ini jika akan menjadi rujukanyuridisolehpara hakim Pengadilan Agama dan harus mempertimbangkan posisi perempuan agar yang cacat badan mendapat perlndungan hukum. Di sisi lain, tumbuh kesadaran mengenai keterbatasan KHI dalam merespon perkembangan masyarakat. Substansi materialnya dianggap tidak mampu mengakomodasi kepentingan perempuan dalam wilayah publik, serta tuntutan perubahan peran perempuan dalam kehidupan keluarga. Di balik tuntutan tersebut, ada harapan untuk menggeser pola relasi suami-istri dari subordinasi kepada kesetaraan dan keadilan. Oleh karena itu, diperlukan kajian ulang terhadap sejumlah pasal yang mencerminkan posisi difabel dalam ruang lingkup pernikahan.

\section{Solusi Atau Bentuk Perlindungan Hukum Terhadap Perempuan Difabel Dalam Pasal 57 Huruf (b) KHI}

Pembaharuan fikih perlu segera dilakukan dengan cara menumbuhkan semangat untuk fikih berwatak humanis. Fikih tidak hanya saja dipraktekkan secara normatif-konservatif, namun harus diejawantahkan dalam kehidupan yang mennyesuakan perkembangan zaman. Oleh sebab itu cara yang efektif adalah menggabungkan antara hukum, keterbukaan serta kemampuan untuk. Lima elemen yang saling terkait, yaitu cognitive nature, wholeness, openness, interrelated hierarchy, and multi-dimensionality. Cognitive nature of the system of Islamic law, berarti menempatkan manusia sebagai subyek yang mengorganisir dan menetapkan ketentuan hukum serta berkemampuan dalam memahami realitas sosial. Wholeness merupakan kemampuan manusia untuk memahami realitas secara utuh, tidak setengah-setengah. Sikap terbuka, interaktif, dan tidak terisolir dari lingkungannya. Intervelated hierarchy berarti sikap menolak hirarki nilai dengan

${ }^{37}$ Siti Ruhaini Dzuhayatin, Kesetaraan antara Perempuan dan Laki-laki ,Pengantar dalam Siti Ruhaini Dz., dkk., Rekonstruksi Metodologis Wacana Kesetaraan Gender dalam Islam (Yogyakarta: PSW IAIN Sunan Kalijaga), 2001, v.

122 | FalASIFA, Vol. 9 Nomor 2 September 2018 
menerima saling keterhubungan antar-nilai. Multi-dimensionality mengandung makna bukan sekadar binary opposition tentang kepastian dan perubahan, melainkan mengakui adanya spektrum dari kepastian ${ }^{38}$

Landasan Kompilasi Hukum Islam (KHI) dimana landasan dalam hal ini ialah sebagai dasar hukum keberadaan Kompilasi Hukum Islam di Indonesia yaitu berlandaskan pancasila dan UUD 1945 dimuat dalam konsiderans Instruksi Presiden dan dalam penjelasan umum KHI disusun sebagai bagian dari sub sistem hukum Islam. ${ }^{39}$

1) Instruksi Presiden No.1 Tahun 1991 tanggal 10 Juni 1991. Disebutkan bahwa kompilasi ini dapat dipergunakan sebagai pedoman dalam penyelesaian masalah-masalah di bidang yang diatur oleh kompilasi, yaitu hukum perkawinan, kewarisan, perwakafan oleh instansi pemerintah dan masyarakat yang memerlukannya;

2) Keputusan Menteri Agama Republik Indonesia tanggal 22 Juli 1991 No.154 Tahun 1991 tentang Pelaksanaan Instruksi Presiden RI No.1 Tahun 1991;

3) Surat Edaran Direktur Pembinaan Badan Peradilan Agama Islam atas nama Direktur Jenderal Pembinaan Kelembagaan Agama Islam tanggal 22 Juli 1991 No.3694/EV/HK.003/AZ/91 yang ditujukan kepada Ketua Pengadilan Tinggi Agama dan Ketua Pengadilan Agama di seluruh Indonesia tentang penyebarluasan Instruksi Presiden RI No.1 Tahun 1991 tanggal 10 Juni 1991.

Berdasarkan dasar hukum atau landasan kompilasi tersebut dapat disimpulkan bahwa KHI mempunyai kedudukan sebagai pedoman dalam artian sebagai sesuatu petunjuk bagi para hakim Peradilan Agama dalam memutuskan dan menyelesaikan perkara. Dengan demikian, maka Peradilan Agama tidak hanya berkewajiban menerapkan ketentuan-ketentuan yang digariskan dalam kompilasi, akan tetapi mempunyai peranan yang lebih besar lagi untuk mengembangkannya dan melengkapinya melalui yurisprudensi yang dibuatnya. Untuk mendapatkan gambaran yang lebih jelas mengenai kedudukan Kompilasi Hukum Islam dalam sistem hukum nasional, dapat dilihat pada tujuan dari kompilasi tersebut, ${ }^{40}$ yaitu :

a) untuk merumuskan secara sistematis hukum Islam di Indonesia secara kongkret;

\footnotetext{
${ }^{38}$ Jasser Auda, Maqasid al-Shariah as Philosophy of Islamic Law: A Systems Approach (London: The International Institute of Islamic Thought, 2008), 45-55.

${ }^{39}$ Cik Hasan Bisri, Peradilan Islam Dalam Tatanan Masyarakat IndonesiaCet. 1 (Bandung: PT Remaja Rosdakarya 1997), 42.

${ }^{40}$ Abdurrahman. "Kompilasi Hukum Islam di Indonesia. (Jakarta : Akademika Pressindo, 1992), 53-62.
}

FalAsIFA, Vol. 9 Nomor 2 September 2018 | 123 
b) guna digunakan sebagai landasan penerapan hukum Islam di lingkungan Peradilan Agama;

c) dan sifat kompilasi, berwawasan nasional yang akan diperlakukan bagi seluruh masyarakat Islam Indonesia;

d) serta sekaligus akan dapat terbina penegakan kepastian hukum yang lebih seragam dalam pergaulan masyarakat Islam.

Dengan demikian pasal 57 huruf (b) bertentangan dengan HAM dan peraturan perundang-undangan dimana secara aturannya peraturan yang lebih tinggi mengenyampingkan peraturan yang lebih rendah. Sebab diatas KHI merupakan sebuah intruksi dan masih belum menjadi hukum positif sedangkan Undang-Undang adalah peraturan yang berada di atasnya. Redaksi pasal 57 huruf (b) yang menyatakan : istri mendapat cacat badan atau penyakit yang tidak dapat disembubkan, tidak relevan sehingga redaksi tersebut tidak perlu masuk dalam rumusan, karena penentuan kalimat cacat badan atau penyakit yang tidak dapat disembuhkan bukan menyangkut persoalan kesehatan fisik, tetapi lebih terkait dengan faktor kedekatan psikologis seseorang sepanjang dibenarkan oleh hukum karena istri yang mendapat cacat badan bisa dicarikan solusi penanganannya seperti melakukan operasi karena jaman di era modern ini cacat badan bisa ditangani oleh medis sehingga landasan Kompilasi Hukum Islam ini di satu sisi hakim harus menggali dan harus peka (memahami) nilai-nilai hukum yang ada di masyarakat dan apabila terwujud maka akan menjadi suatu prestasi besar dalam upaya mewujudkan kesatuan norma hukum Islam secara tertulis ialah perlu mengatur ulang ketentuan pasal 57 huruf $\mathrm{b}$ dan hakim harus memperketat untuk tidak mengabulkan suami yang hendak poligami karena alasan tersebut.

\section{KESIMPULAN}

Ketentuan pasal 57 huruf b KHI tersebut bertentangan dengan HAM, Undang-Undang Nomor 4 Tahun 1997 Tentang Penyandang cacat, UndangUndangDasarRepublik Indonesia Tahun 1945, Undang-undang Nomor 19 Tahun 2011 Tentang Pengesahan Konvensi Disabilitas dan Undang-Undang Nomor 8 Tahun 2016 Tentang Disabilitas. Solusinya ialah perlu mengatur ulang ketentuan pasal 57 huruf $\mathrm{b}$ dan hakim harus memperketat untuk tidak mengabulkan suami yang hendak poligami karena alasan tersebut. Fikih sangat diharapkan dapat menjamin rasa keadilan umat dengan cara melahirkan semangat untuk meneguhkan sosiologi pemberdayaan fikih agar tidak surut ke belakang. Dengan demikian, kaum minoritas dan perempuan dilindungi dan dijamin hakhaknya secara adil dan merata yang sejalan tujuan sosial yang merata di lapisan masyarakat sebab Redaksi pasal 57 huruf (b) yang menyatakan : istri mendapat 
cacat badan atau penyakit yang tidak dapat disembubkan, tidak relevan sehingga redaksi tersebut tidak perlu masuk dalam rumusan, karena penentuan kalimat cacat badan atau penyakit yang tidak dapat disembuhkan bukan menyangkut persoalan kesehatan fisik, tetapi lebih terkait dengan faktor kedekatan psikologis seseorang sepanjang dibenarkan oleh hukum karena istri yang mendapat cacat badan bisa dicarikan solusi penanganannya.

\section{DAFTAR PUSTAKA}

Abdurrahman. Kompilasi Hukum Islam di Indonesia. Jakarta: Akademika Pressindo. 1992.

Auda, Jasser. Maqasid al-Shariah as Philosophy of Islamic Law: A Systems Approach. London: The International Institute of Islamic Thought. 2008.

Bisri, Cik Hasan. Peradilan Islam Dalam Tatanan Masyarakat Indonesia. Cet.1. Bandung. PT Remaja Rosdakarya. 1997.

Dz, Siti Ruhaini. dkk., Rekonstruksi Metodologis Wacana Kesetaraan Gender dalam Islam. Yogyakarta: PSW IAIN Sunan Kalijaga. 2001

Husodo, Siswono Yudo. Menuju Welfare State, Kumpulan Tulisan tentang Kebangsaan, Ekonomi, dan Politik. Jakarta: Baris Baru. 2009.

Kurniawan, Hari. Aksesibiltas Peradilan Bagi Penyandang Disabilitas. Yogyakarta:PUSHAM UII. 2015.

Lim Francis, "Filsafat Teknologi: Don Ihde Tentang Manusia dan Alat. Yogyakarta: KANISIUS, 2008.

Marzuki, Peter Mahmud. Penelitian Hukum Edisi Revisi. Jakarta: Pranada Media Group. 2015.

Moleong, Lexy J. metodologi penelitian kualitatif . Bandung: Remaja Rosdakarya. 2010.

Munir,'Pembelajaran Jarak Jauh : Berbasis Teknologi Informasi dan Komunikasi. Bandung: ALFABETA, 2009.

Sadli, Saparinah. Sekapur Sirih, dalam Masdar F. Mas'udi, Islam dan Hak-hak Reproduksi Perempuan. Bandung: Mizan. 2000.

Sentanu, ErbeQuatumIkhlas :TeknologiAktivasiKekuatanHati The Power Of Positive Feeling. Jakarta: PT. Elex Media Komputindo. 2011.

Sugiyono. Metode Penelitian Kuantitatif dan Kualitatif dan R\&D. Bandung: Alfabeta. 2014.

Harahap, Rahayurepindowaty. 2015 perlindunganhukumterhadappenyandang disabilitasmenurut convention on the rights of persons with disabilities (crpd) vol VIII, 2015.

Isya M. dkk., aksesibilitas jembatan penyeberangan orang (jpo) bagi penyandang

Falasifa, Vol. 9 Nomor 2 September $2018 \mid 125$ 
Amir Fiqih Alqadafi

difabel di kota banda Aceh menurut persepsi masyarakat. Teras Jurnal, Vol.5, 2015.

Mujimin, W. M., Dinamika Pendidikan: Penyediaan Fasilitas Publik yang Manusiawi Bagi Aksesibilitas Difabel. No.1/Th.XIV/ Yogyakarta.: Universitas Negeri. 2007.

Sodik, Mochamad. Pembacaan Progresf Terhadap Fikih Keluarga: Kritik Terhadap KHI dan RUU HTPA. vol 4, 2012.

Undang-Undang Dasar Negara Republik Indonesia Tahun 1945

Undang-Undang Nomor 8 Tahun 2016 Tentang Disabilitas

Undang-Undang HAM Nomor 39 tahun 1999 tentang HAM

Undang-Undang Nomor 4 Tahun 1997 Tentang Penyandang Cacat

Undang-Undang Nomor 19 Tahun 2011 Tentang Pengesahan Konvensi Mengenai Hak-Hak Penyandang Disabilitas 